\title{
Pengaruh ekspor, tingkat inflasi dan nilai tukar mata uang terhadap cadangan devisa (studi di Indonesia dan Malaysia)
}

\author{
Nanda Eulia*; Syaparuddin; Parmadi \\ Prodi Ekonomi Pembangunan, Fak.Ekonomi dan Bisnis, Universitas Jambi \\ *E-mail korespodensi: Euliagumay48@gmail.com
}

\begin{abstract}
This study aims at the implications of the development of foreign exchange reserves, exports, inflation, and the exchange rate of the rupiah and Malaysian ringgit for the period 2000-2017, the implications of the effect of exports, inflation, and the rupiah exchange rate on foreign exchange reserves in Indonesia and the effect of exports, inflation and the value of the rupiah. exchange rate ringgit against Foreign Exchange Reserves in Malaysia. The type of data used in this study is secondary data which is periodic data from $2000-2017$, hypothesis testing itself using multiple linear regression equations. The analytical tools used are the joint test (F-Test), Partial Regression Coefficient Test (t-test), and Classical Assumption Test. Based on the t-test analysis, it can be seen that exports cannot affect foreign exchange reserves. Meanwhile, inflation has a negative and significant effect on foreign exchange reserves with a coefficient of $0.159 \%$ and the exchange rate has a positive and significant effect on foreign exchange reserves with a coefficient of $1.446 \%$.
\end{abstract}

Keywords: Exports, Inflation, Exchange rates, Foreign reserves

\begin{abstract}
Abstrak
Penelitian ini bertujuan untuk implikasi perkembangan cadangan devisa, ekspor, inflasi dan nilai tukar mata uang rupiah dan ringgit Malaysia periode 2000-2017, implikasi pengaruh ekspor, inflasi dan nilai tukar mata uang rupiah terhadap Cadangan Devisa di Indonesia dan untuk pengaruh ekspor, inflasi dan nilai tukar mata uang ringgit terhadap Cadangan Devisa di Malaysia. Jenis data yang digunakan dalam penelitian ini adalah data sekunder yang merupakan data berkala dari tahun 2000 - 2017, pengujian hipotesis sendiri menggunakan persamaan regresi linear berganda. Alat analisis yang digunakan adalah Uji secara bersamasama (Uji-F), Uji Koefisien Regresi Parsial (Uji-t), dan Uji Asumsi Klasik. Berdasarkan analisis uji t, dapat dilihat ekspor tidak dapat mempengaruhi cadangan devisa. Sementara inflasi berpengaruh negatif dan signifikan terhadap cadangan devisa dengan koefisien sebesar $0,159 \%$ dan nilai tukar berpengaruh positif dan signifikan terhadap cadangan devisa dengan koefisien sebesar 1,446\%.
\end{abstract}

Kata kunci: Ekspor, Inflasi, Kurs, Cadangan devisa

\section{PENDAHULUAN}

Kebutuhan masyarakat yang semakin meningkat dan beragam jenisnya tidak dapat dipenuhi seluruhnya oleh produksi yang dihasilkan di dalam negeri semata. Kenaikan kapasitas produksi dari berbagai komoditi membutuhkan pasar yang lebih luas dari luar negeri. Keadaan tersebut mendorong terjadinya kegiatan perdagangan antar negara baik barang maupun jasa yang terus menerus meningkat nilainya. 
Inflasi merupakan masalah yang penuh perhatian di negara manapun. Kenaikan harga menyebabkan barang-barang negara itu tidak dapat bersaing di pasaran internasional sehingga ekspor akan menurun (Sukirno, 2006). Tingkat persentase inflasi di Indonesia pada tahun 2013 sebesar 8,38\% dan mengalami penurunan pada tahun 2014 menjadi 8,36\%. Pada tahun 2015 terjadi penurunan menjadi 3,35\% di tahun 2015 terjadi penurunan sehingga tingkat inflasi menjadi 3,02\% namun di tahun 2017 terjadi peningkatan sehingga tingkat inflasi menjadi 3,61\%.

Pasca diberlakukannya sistem nilai tukar mengambang penuh/bebas (freely floating exchange rate), posisi nilai tukar rupiah terhadap mata uang asing (khususnya US\$) ditentukan oleh mekanisme pasar. Pada waktu itu nilai tukar rupiah secara simultan mendapatkan tekanan yang cukup berat karena besarnya capital outflow akibat hilangnya kepercayaan investor asing terhadap prospek perekonomian Indonesia. Tekanan terhadap nilai tukar tersebut diperberat lagi dengan semakin maraknya kegiatan spekulatif buble, sehingga sejak krisis berlangsung nilai tukar sempat mengalami depresiasi hingga mencapai 75\% (Goeltom, 1998).

Pada tahun 2013 nilai tukar rupiah terhadap dollar yaitu Rp. 10.451,37 dan mengalami penaikan sebesar 13,65\% sehingga pada tahun 2014 rupiah terhadap dollar menjadi Rp. 11.878,30. Pada tahun 2015 terjadi peningkatan sebesar 12,73\% sehingga rupiah terhadap dollar menjadi Rp. 13.391,97 dan di tahun 2016 terjadi menurunan sebesar 0,62\% sehingga nilai dollar terhadap rupiah menjadi Rp. 13.307,38 dan di tahun 2017 mengalami peningkatan sebesar $0,57 \%$ sehinggaa nilai dollar terhadap rupiah menjadi Rp. 13.384,13.

Berdasarkan latar belakang yang telah dipaparkan maka penulis tertarik untuk menganalisis "pengaruh nilai ekspor, tingkat inflasi,dan nilai tukar mata uang terhadap cadangan devisa (studi di Indonesia dan Malaysia)".

\section{METODE}

Jenis penelitian yang digunakan dalam penelitian ini adalah penelitian kuantitatif. Metode penelitian kuantitatif merupakan salah satu jenis penelitian yang spesifikasinya adalah sistematis, terencana dan terstruktur dengan jelas sejak awal hingga pembuatan desain penelitiannya. Data yang digunakan dalam penelitian ini merupakan data sekunder yang merupakan data berkala dari tahun 2000 - 2017, sumber data dalam penelitian ini diperoleh dari website Asian Development Bank (ADB).

\section{Metode analisis data}

Analisis deskriptif adalah statistik yang digunakan untuk menganalisis data dengan cara mendeskripsikan atau menggambarkan data yang telah terkumpul sebagaimana adanya tanpa bermaksud membuat kesimpulan yang berlaku untuk umum atau generalisasi (Sugiyono,2015). Analisis ini hanya merumuskan dan menyimpulkan data yaitu dengan cara membuka atau melihat data tabulasi yang ada dan menganalisisnya. Untuk mengalalisis data digunakan rumus sebagai berikut :

Dimana :

$$
G_{X}=\frac{X_{t}-X_{t-1}}{X_{t-1}} X 100 \%
$$

$\mathrm{Gx}=$ Laju perkembangan $\mathrm{x}$

$\mathrm{X}_{\mathrm{t}}=$ Data $\mathrm{x}$ tahun tertentu

$\mathrm{X}_{\mathrm{t}}-1=$ Data $\mathrm{x}$ tahun sebelumnya 


\section{Analisis kuantitatif}

Analisis kuantitatif adalah analisis yang dilakukan dengan cara menguji dan mengumpulkan data untuk menguji pengaruh antara variabel bebas terhadap variabel terikat (Yulmardi dkk, 2009). Adapun model persamaanya adalah :

$Y=\alpha+\beta_{1} X_{1}+\beta_{2} X_{2}+B_{3} X_{3}+\mu t$

Untuk penelitian ini maka formulasi disederhanakan menjadi:

$\mathrm{CD}=\boldsymbol{\alpha}_{0}+\beta_{1} \mathrm{EKS}+\beta_{2} \mathrm{INFL}+\boldsymbol{B}_{3} \mathrm{KURS}+\mu_{t}$

Dalam perhitungan dilakukan untuk kedua Negara yaitu Indonesia dan Malaysia sehingga rumus di jabarkan kembali menjadi:

Untuk Indonesia

$$
\begin{aligned}
& \mathrm{CD}_{\mathrm{IND}}=\boldsymbol{\beta}_{0}+\boldsymbol{\beta}_{1} \mathrm{EKS}_{\mathrm{IND}}+\boldsymbol{\beta}_{2} \mathrm{INFL}_{\mathrm{IND}}+\boldsymbol{B}_{3} \mathrm{KURS}_{\mathrm{IND}}+\boldsymbol{\mu}_{t} \\
& \mathrm{CD}_{\mathrm{MAS}}=\boldsymbol{\beta}_{0}+\boldsymbol{\beta}_{1} \mathrm{EKS}_{\mathrm{MAS}}+\boldsymbol{\beta}_{2} \mathrm{INFL} \mathrm{INAS}_{\mathrm{MA}}+\boldsymbol{B}_{3} \mathrm{KURS}_{\mathrm{MAS}}+\boldsymbol{\mu}_{t}
\end{aligned}
$$

Dimana :

$\begin{array}{ll}\mathrm{CD}_{\text {IND }} & =\text { Cadangan devisa indonesia } \\ \mathrm{CD}_{\text {MAS }} & =\text { Cadangan devisa malaysia } \\ \text { Eks }_{\text {IND }} & =\text { Ekspor Indonesia } \\ \mathrm{Eks}_{\text {MAS }} & =\text { Ekspor Malaysia } \\ \text { Infl }_{\text {IND }} & =\text { Inflasi Indonesia } \\ \text { Infl }_{\text {MAS }} & =\text { Inflasi Malaysia } \\ \text { Kurs IND }_{\text {Kurs }} & =\text { Kurs Indonesia } \\ \text { KuS }_{\text {M }} & =\text { Kurs Malaysia }\end{array}$

Model ekonometrika yang digunakan dalam penelitian ini adalah model regresi linear berganda bertujuan untuk melihat pengaruh antara variabel bebas terhadap variabel terikat yang terdapat dalam model ekonometrika.

\section{Pengujian hipotesis}

\section{Uji koefisien regresi secara bersama-sama (Uji F)}

Uji F digunakan untuk menguji secara kolektif pengaruh ekspor (X1), inflasi (X2), nilai tukar mata uang (X3) terhadap cadangan devisa. Uji F disebut juga uji kelayakan model yang digunakan untuk mengidentifikasi model yang diasumsi layak atau tidak. Layak di sini berarti bahwa model yang diestimasi layak digunakan untuk menjelaskan pengaruh variabel-variabel independen terhadap variabel dependen. Apabila nilai probabilitas $\mathrm{F}$ hitung < tingkat signifikansi 0,05 maka dapat dikatakan bahwa model regresi yang diestimasi layak (Ariefianto, 2012).

\section{Uji koefisien regresi parsial (Uji t)}

Ariefianto (2012) model uji-t ini digunakan untuk menguji pengaruh variabel bebas secara parsial terhadap variabel terikat. Kriteria pengambilan keputusan:

(1) Jika probabilitas t hitung $<\alpha(0.05)$, maka H0 ditolak

(2) Jika probabilitas t hitung $>\alpha(0.05)$, maka $\mathrm{H}_{0}$ diterima 


\section{Koefisien determinasi}

Koefisien determinasi $\left(\mathrm{R}^{2}\right)$ dilakukan untuk mendeteksi ketepatan yang paling baik dari hasil regresi.Pengujian ini dilakukan dengan melihat besarnya nilai koefisien determinasi, $\mathrm{R}^{2}$ merupakan besaran non negatif dan besarnya koefisien determinasi adalah antara angka nol sampai dengan angka satu $\left(0 \leq \mathrm{R}^{2} \leq 1\right)$. Koefisien determinasi bernilai nol berarti tidak ada hubungan antara variabel bebas dengan terikat. Sebaliknya nilai koefisien determinasi bernilai satu berarti terdapat suatu kecocokan sempurna dari ketepatan model.

\section{Uji asumsi klasik}

Pengujian model terhadap asumsi klasik diberlakukan pada persamaan struktural yang meliputi Uji Normalitas, Uji Multikolinearitas, Uji Autokorelasi dan Uji Heterokedasitas :

\section{Uji normalitas}

Uji normalitas bertujuan untuk melihat apakah residualnya terdistribusi secara normal atau tidak dengan asumsi model regresi yang Best Linear Unbias Estimator (BLUE) dari klasik adalah dengan membandingkan nilai Jarque-Berra dengan nilai Chi-Square $\left(X^{2}\right)$.Jika nilai Jarque-Berra lebih kecil dari nilai tabel Chi-Square $\left(X^{2}\right)$, maka dikatakan model lolos dari ketidaknormalan distribusi residualnya (Insukindro, 2004).

\section{Uji multikolinearitas}

Sebuah model yang mengandung multikolinieritas dapat ditunjukkan oleh indikasi sebagi berikut (Gujarati, 1995) $: R^{2}$ tinggi, tetapi sedikit t statistic yang signifikanadanya korelasi yang tinggi antara variable

\section{Uji autokorelasi}

Autokorelasi dapat terjadi apabila kesalahan pengganggu suatu periode korelasi dengan kesalahan penggangu periode sebelumnya. Pengujian autokorelasi dilakukan dengan eviews, alat yang digunakan adalah Breusch-Godfrey serial Correlation LM test. Jika nilaia Obs*R-square hasil pengujian serial Correlation LM test lebih kecil dari nilai tabel Chi-Square $\left(X^{2}\right)$ maka lolos dari adanya autokorelasi (Insukindro, 2004).

\section{Uji heterokedasitas}

Heteroskedastisitas terjadi bila variabel gangguan mempunyai varibael yang sama untuk observasi, untuk mendeteksi ada atau tidaknya heteroskedastisitas digunakan uji White's heteroskedastisitas test. Jika nilai Chi-Square hitung lebih kecil dari nilai ChiSquare tabel $\left(X^{2}\right)$ menunjukkan tidak adanya heteroskedastisitas.(Gujarati, 2015).

\section{HASIL DAN PEMBAHASAN}

\section{Perkembangan nilai ekspor, inflasi dan nilai tukar rupiah terhadap cadangan devisa Tahun 2000-2017}

Ekspor yang dilakukan Indonesia yang mengalami fluktuasi setiap tahunnya. Pada tahun 2010 terjadi peningkatan sebesar 35,42\% dimana pada periode 2000-2017 ini merupakan peningkatan terbesar, hal tersebut dipengaruhi oleh membaiknya kinerja ekspor beberapa produk utama Indonesia seperti batu bara, minyak kelapa, minyak kelapa sawit, tembaga refinery. Selanjutnya perkembangan ekspor yang dilakukan oleh Negara Malaysia dari tahun 2000-2017 yang mengalami fluktuasi, dimana pada tahun 2004 terjadi 
peningkatan yang paling tinggi sepanjang tahun penelitian dengan perkembangan meningkat sebesar $21,09 \%$.

Inflasi yang mengalami fluktuasi setiap tahunnya. Pada tahun 2005 terjadi peningkatan sebesar 167,34\% dimana pada periode 2000-2017 ini merupakan peningkatan terbesar, hal tersebut dipengaruhi kenaikan administred price, khususnya harga BBM pada bulan maret dan oktober 2005, selain itu juga terjadi kenaikan administeres price lainnya seperti tariff angkutan, elpiji, cukai rokok dan tarif tol. Laju inflasi ini juga disebabkan adanya gangguan pasokan dan distribusi sehungga menyebabkan tingginya harga bahan makanan (volatile foods), adanya peningkatan ekspektasi inflasi didorong oleh kenaikan harga BBM dan pelemahan nilai tukar rupiah.Selanjutnya perkembangan inflasi yang terjadi di Negara Malaysia, dimana perkembangan tersebut berfluktuasi pada periode 20002017. Peningkatan tertinggi terjadi pada tahun 2010 dengan nilai perkembangan sebesar $183,33 \%$.

Nilai tukar rupiah yang mengalami fluktuasi setiap tahunnya. Pada tahun 2001 terjadi peningkatan sebesar 21,54\% dimana pada periode 2000-2017 ini merupakan peningkatan terbesar, hal tersebut dipengaruhi oleh dua indikator yaitu faktor-faktor pendorong ( $p u s h$ factors) berupa sentiment negaif atas kondisi perekonomian AS, dimana seiring intensitas perang dagang antara AS vs China menyebabkan pertumbuhan ekonomi AS justru mengalami perlambatan. Selanjutnya perkembangan nilai tukar ringgit terhadap dollar, dimana perkembangan tersebut berfluktuasi pada periode 2000-2017. Peningkatan tertinggi terjadi pada tahun 2015 dengan nilai perkembangan sebesar 19,57\%.

Cadangan devisa Indonesia yang mengalami fluktuasi setiap tahunnya. Pada tahun 2010 terjadi peningkatan sebesar 48,53\% dimana pada periode 2000-2017 ini merupakan peningkatan terbesar, hal tersebut dipengaruhi oleh penerimaan devisa migas, penerbitan global bonds (surat utang global) dan penarikan pinjaman luar negeri pemerintah. Selanjutnya perkembangan cadangan devisa Malaysia, dimana perkembangan tersebut berfluktuasi pada periode 2000-2017. Peningkatan tertinggi terjadi pada tahun 2004 dengan nilai perkembangan sebesar 51,74\%. Pengujian ini menggunakan regresi linear berganda untuk mengetahui tujuan yang telah dituliskan sebelumnya yaitu menganalisis besarnya pengaruh ekspor, inflasi dan kurs terhadap Cadangan Devisa .

\section{Pengaruh nilai ekspor, inflasi dan nilai tukar rupiah terhadap cadangan devisa indonesia Tahun 2000-2017}

Permodelan dalam menggunakan tekni regresi linear berganda yang menggunakan model pendekatan OLS (ordinary least square). Berikut ini hasil olahan terdapat pada Tabel 1.

Tabel 1. Hasil analisis regresi linear berganda

\begin{tabular}{llrrrr}
\hline & B & Std. Error & Beta & t & \multicolumn{1}{c}{ sig } \\
\hline (Constant) & 4.014 & .798 & & 5.033 & .000 \\
EKS_IND & -.058 & .045 & -.220 & -1.291 & .218 \\
INFLS_IND & -.519 & .197 & -.490 & -2.628 & .020 \\
KURS_IND & 1.446 & .674 & .399 & 2.148 & .050 \\
\hline
\end{tabular}

Sumber: Data diolah, 2018

Hasil dari pengolahan data dengan pendekatan OLS (Ordinary Least Square) sebagai berikut:

$$
Y=4,014-0,058 X_{1}-0,519+1,446 X_{3}+e
$$


Berdasarkan model estimasi dengan pendekatan OLS (Ordinary Least Square) maka dapat dijelaskan beberapa hal sebagai berikut:

Nilai constanta sebesar 4,014, artinya jika ekspor $\left(\mathrm{X}_{1}\right)$, inflasi $\left(\mathrm{X}_{2}\right)$ dan kurs $\left(\mathrm{X}_{3}\right)$ diasumsikan 0 , maka secara konstan cadangan devisaIndonesia (Y) bernilai 4,014.Koefisien regresi variable nilai ekspor $\left(\mathrm{X}_{1}\right)$ sebesar- 0,058 artinya, jika nilai ekspor $\left(\mathrm{X}_{1}\right)$ naik satu satuan maka cadangan devisa $(\mathrm{Y})$ akan menurunkan cadangan devisa Indonesia sebesar 0,058. Koefisien regresi variable inflasi $\left(\mathrm{X}_{2}\right)$ sebesar $-0,519$ artinya, jika inflasi $\left(\mathrm{X}_{2}\right)$ naik satu satuan maka cadangan devisa $(\mathrm{Y})$ akan menurun sebesar 0,519.

1. Koefisien regresi variable kurs $\left(\mathrm{X}_{3}\right)$ sebesar 1,446 artinya, jika kurs $\left(\mathrm{X}_{2}\right)$ naik satu satuan maka cadangan devisa (Y) akan meningkat sebesar 1,446.

\section{Uji asumsi klasik}

\section{Uji multikolineritas}

Untuk mengetahui apakah terjadi multikolinieritas dalam suatu model regresi dapat dilihat dari nilai VIF (variance Inflation Factor). Apabila nilai tolerance < 0,1 dan VIF > 10 (variance Inflation Factor) mengindikasikan terjadi multikolinieritas.

Tabel 2. Hasil uji multikolinearitas

\begin{tabular}{lccc}
\hline & Tolerance & VIF & \\
\hline (Constant) & & & \\
EKS_IND & .993 & 1.007 \\
INFLS_IND & .833 & 1.201 \\
KURS_IND & .836 & 1.196 \\
\hline
\end{tabular}

Sumber: Data diolah, 2018

Dari hasil penelitian pada Tabel 2 terlihat bahwa nilai Tolerance dan VIF menunjukkan bahwa tidak ada satu variabel independen yang memiliki nilai VIF lebih besar dari 10 dan tidak ada satu nilai Tolerance variabel independen yang memenuhi nilai tolerance yaitu kurang dari 0,1 . Nilai variable ekspor yaitu: Tolerance $(0,993)$ dan VIF (1.007), nilai variable inflasi yaitu: Tolerance $(0,833)$ dan VIF (1.201) dan nilai variable kurs Tolerance $(0,836)$ dan VIF $(1.196)$.

\section{Uji autokorelasi}

Uji Durbin Watson akan menghasilkan nilai Durbin Watson (DW) yang nantinya akan dibandingkan dengan dua (2) nilai Durbin Watson table, yaitu Durbin Uper (DU) dan Durbin Lower (DL). Dikatakan tidak terdapat autokorelasi jika nilai DW > DU dan (4-DW) $>$ DU atau bias dinotasikan juga sebagai berikut: $(4-D W)>$ DU $<$ DW.

Tabel 3. Hasil uji autokorelasi

\begin{tabular}{cccc}
\hline R & R Square & Adjusted R Square & Durbin Watson \\
\hline $.772^{\mathrm{a}}$ & .595 & .509 & 1.215 \\
\hline
\end{tabular}

Sumber: Data diolah, 2018

Berdasarkan hasil perhitungan analisis data dengan menggunakan SPSS versi 20 diperoleh hasil uji autokorelasi seperti tabel 5.7. dari tabel tersebut dapat dilihat angka Durbin-Watson Test sebesar 1,215.Karena angka D-W test 1,215 terletak diantara nilai dL 
sebesar 0,7790 dan nilai dU 2.9005 maka $0,7790>1,215<2,9005$, maka dapat disimpulkan bahwa tidak terjadi autokorelasi pada model ini.

\section{Uji hipotesis}

Untuk uji hipotesis dilakukan dengan uji signifikasi statistik secara simultan dan parsial dengan uji satu arah. Berikut ini dijelaskan uji simultan dan uji parsial:

\section{Uji secara bersama-sama (uji F)}

Pengujian statistik simultan atau uji-f digunakan untuk pengujian terhadap pengaruh semua variabel independen didalam model. Uji $\mathrm{F}$ pada dasarnya menunjukkan apakah semua variabel independen yang dimasukkan dalam model mempunyai pengaruh secara bersama-sama terhadap variabel dependen.

Tabel 4. Hasil uji secara bersama-sama (uji F)

\begin{tabular}{llrrrrrr}
\hline & Model & Sum of Squares & df & $\begin{array}{c}\text { Mean } \\
\text { Square }\end{array}$ & \multicolumn{1}{l}{ F } & Sig. & \\
\hline 1 & Regression & .593 & 3 & .198 & 6.868 & & $.004^{\mathrm{b}}$ \\
& Residual & .403 & 14 & .029 & & & \\
& Total & .995 & 17 & & & & \\
\hline
\end{tabular}

Sumber: Data diolah, 2018

Tabel 4 diperoleh nilai $\mathrm{F}$ hitung sebesar 6.868 dengan signifikansi sebesar 0,004 . Dengan nilai signifikan sebesar 0,004 yang artinya lebih kecil dari 0,05 maka dapat disimpulkan bahwa secara simultan ekspor $\left(\mathrm{X}_{1}\right)$, inflasi $\left(\mathrm{X}_{2}\right)$ dan kurs $\left(\mathrm{X}_{3}\right)$ berpengaruh signifikan terhadap cadangan devisa Indonesia.

\section{Uji parsial (uji t)}

Pengujian statistik parsial atau uji-t digunakan untuk pengujian terhadap pengaruh satu per satu variabel independen didalam model. Uji t pada dasarnya menunjukkan apakah semua variabel independen yang dimasukkan dalam model mempunyai pengaruh secara satu per satu terhadap variabel dependen.

Tabel 5. Hasil uji parsial (Uji t)

\begin{tabular}{lcrrrr}
\hline & B & Std. Error & Beta & \multicolumn{1}{c}{ t } & Sig \\
\hline (Constant) & 4.014 & .798 & & 5.033 & .000 \\
EKS_IND & -.058 & .045 & -.220 & -1.291 & .218 \\
INFLS_IND & -.519 & .197 & -.490 & -2.628 & .020 \\
KURS_IND & 1.446 & .674 & .399 & 2.148 & .050 \\
\hline
\end{tabular}

Sumber: Data diolah, 2018

Berdasarkan Tabel 5 dijelaskan bahwa Ekspor $\left(\mathrm{X}_{1}\right)$, Untuk variabel ekspor (X1) diperoleh nilai t hitung sebesar -1,291 dengan tingkat signifikan sebesar 0,218. Hasil dari uji regresi menunjukkan bahwa secara parsial ekspor $\left(\mathrm{X}_{1}\right)$ tidak berpengaruh terhadap cadangan devisa $(\mathrm{Y})$ karena tingkat signifikan lebih besar dari 0,05. Inflasi $\left(\mathrm{X}_{2}\right)$, Untuk variabelinflasi $\left(\mathrm{X}_{2}\right)$ diperoleh nilait hitung sebesar -2.628 dengan tingkat signifikan sebesar 0,020 . Hasil ini menunjukkan bahwa secara parsial inflasi $\left(X_{2}\right)$ berpengaruh terhadap cadangan devisa (Y) karena tingkat signifikan lebih kecil dari 0,05. Kurs $\left(\mathrm{X}_{3}\right)$, Untuk variabel kurs $\left(\mathrm{X}_{3}\right)$ diperoleh nilai t hitung sebesar 2.148 dengan tingkat signifikan sebesar 
0,050. Hasil dari uji ini menunjukkan bahwa secara parsial kurs $\left(\mathrm{X}_{3}\right)$ berpengaruh terhadap cadangan devisa $(\mathrm{Y})$ karena tingkat signifikan sama dengan 0,05 .

\section{Uji koefisien determinasi $\left(\mathbf{R}^{2}\right)$}

Untuk mengetahui besarnya persentase pengaruh variabel bebas (independen) terhadap variabel terikat (dependen) yang dapat dilihat dari tabel berikut ini:

Tabel 6. Hasil uji determinasi

\begin{tabular}{cccc}
\hline $\mathbf{R}$ & R Square & Adjusted R Square & $\begin{array}{c}\text { Durbin- } \\
\text { Watson }\end{array}$ \\
\hline $.772^{\mathrm{a}}$ & .595 & .509 & 1.215 \\
\hline
\end{tabular}

Sumber: Data diolah, 2018

Nilai R Square $=0,509$ dapat diarikan besarnya nilai ekspor $\left(\mathrm{X}_{1}\right)$, inflasi $\left(\mathrm{X}_{2}\right)$ dan kurs $\left(\mathrm{X}_{3}\right)$ mampu mempengaruhi cadangan devisa Indonesia $(\mathrm{Y})$ sebesar 50,9\% sedangkan sisanya sebesar $49,1 \%$ dipengaruhi atau dijelaskan oleh variabel lain yang tidak termasuk dalam penelitian ini.

Pengaruh nilai ekspor, inflasi dan nilai tukar rupiah terhadap cadangan devisa malaysia periode $2000-2017$

Permodelan dalam menggunakan tekni regresi linear berganda yang menggunakan model pendekatan OLS (Ordinary Least Square).

Tabel 7. Hasil analisis regresi linear berganda

\begin{tabular}{|c|c|c|c|c|c|}
\hline & B & Std. Error & Beta & $\mathbf{t}$ & Sig \\
\hline (Constant) & 6.160 & .699 & & 8.810 & .000 \\
\hline EKS_MYR & .005 & .068 & .015 & .072 & .944 \\
\hline INFLS_MYR & .305 & .217 & .304 & 1.408 & .181 \\
\hline KURS_MYR & -2.519 & 1.095 & -.494 & -2.301 & .037 \\
\hline
\end{tabular}

Sumber: Data diolah, 2018

Hasil dari pengolahan data dengan pendekatan OLS (Ordinary Least Square) sebagai berikut:

$$
Y=6,160+0,005 X_{1}+0,305-2,519 X_{3}+e
$$

Berdasarkan model estimasi dengan pendekatan OLS (Ordinary Least Square) maka dapat dijelaskan beberapa hal sebagai berikut: Nilai constanta sebesar 6,160, artinya jika ekspor $\left(\mathrm{X}_{1}\right)$, inflasi $\left(\mathrm{X}_{2}\right)$ dan kurs $\left(\mathrm{X}_{3}\right)$ diasumsikan 0 , maka secara konstan cadangan devisa Malaysia $(Y)$ bernilai 6,160. Koefisien regresi variable nilai ekspor $\left(\mathrm{X}_{1}\right)$ sebesar 0,005 artinya, jika nilai ekspor $\left(\mathrm{X}_{1}\right)$ naik satu satuan maka cadangan devisa(Y) akan meningkatkan cadangan devisa Malaysia sebesar 0,005. Koefisien regresi variable inflasi $\left(\mathrm{X}_{2}\right)$ sebesar 0,305 artinya, jika inflasi $\left(\mathrm{X}_{2}\right)$ naik satu satuan maka cadangan devisa Malaysia $(\mathrm{Y})$ akan meningkat sebesar 0,305 . Koefisien regresi variable nilai tukar $\left(\mathrm{X}_{3}\right)$ sebesar -2,519 artinya, jika kurs $\left(\mathrm{X}_{2}\right)$ naik satu satuan maka cadangan devisa Malaysia(Y) akan menurun sebesar 2,519. 


\section{Uji asumsi klasik}

\section{Uji multikolineritas}

Untuk mengetahui apakah terjadi multikolinieritas dalam suatu model regresi dapat dilihat dari nilai VIF (variance Inflation Factor). Apabila nilai tolerance $<0,1$ dan VIF $>$ 10 (variance Inflation Factor) mengindikasikan terjadi multikolinieritas.

Tabel 8. Hasil uji multikolinearitas

\begin{tabular}{llcc}
\hline & Tolerance & VIF \\
\hline 1 & (Constant) & & \\
& EKS_MYR & .990 & 1.010 \\
& INFLS_MYR & .986 & 1.015 \\
& KURS_MYR & .995 & 1.005 \\
\hline
\end{tabular}

Sumber: Data diolah, 2018

Tabel 6 terlihat menunjukkan bahwa tidak ada satu variabel independen yang memiliki nilai VIF lebih besar dari 10 dan tidak ada satu nilai Tolerance variabel independen yang memenuhi nilai tolerance yaitu kurang dari 0,1 . Nilai variable ekspor yaitu: Tolerance $(0,990)$ dan VIF $(1.010)$, nilai variable inflasi yaitu: Tolerance $(0,986)$ dan VIF (1.015) dan nilai variable kurs Tolerance $(0,995)$ dan VIF $(1.005)$.

\section{Uji autokorelasi}

Uji Durbin Watson akan menghasilkan nilai Durbin Watson (DW) yang nantinya akan dibandingkan dengan dua (2) nilai Durbin Watson table, yaitu Durbin Uper (DU) dan Durbin Lower (DL). Dikatakan tidak terdapat autokorelasi jika nilai DW > DU dan (4-DW) $>$ DU atau bias dinotasikan juga sebagai berikut: (4-DW) $>$ DU $<$ DW.

Tabel 9. Hasil uji autokorelasi

\begin{tabular}{ccccc}
\hline Model & R & R Square & $\begin{array}{c}\text { Adjusted R } \\
\text { Square }\end{array}$ & Durbin-Watson \\
\hline 1 & $.598^{\mathrm{a}}$ & .358 & .220 & 1.629 \\
\hline
\end{tabular}

Sumber: Data diolah, 2018

Berdasarkan hasil perhitungan analisis data dengan menggunakan SPSS versi 20 diperoleh hasil uji autokorelasi seperti tabel 5.7. dari tabel tersebut dapat dilihat angka Durbin-Watson Test sebesar 1,629.Karena angka D-W test 1,262915 terletak diantara nilai dL sebesar 0,7790 dan nilai dU 2.9005 maka $0,7790>1,629<2,9005$, maka dapat disimpulkan bahwa tidak terjadi autokorelasi pada model ini.

\section{Uji hipotesis}

Untuk uji hipotesis dilakukan dengan uji signifikasi statistik secara simultan dan parsial dengan uji satu arah. Berikut ini dijelaskan uji simultan dan uji parsial:

\section{Uji secara bersama-sama (Uji F)}

Pengujian statistik simultan atau uji-f digunakan untuk pengujian terhadap pengaruh semua variabel independen didalam model. Uji $\mathrm{F}$ pada dasarnya menunjukkan apakah semua variabel independen yang dimasukkan dalam model mempunyai pengaruh secara bersama-sama terhadap variabel dependen. 
Tabel 10. Hasil uji secara bersama-sama (Uji F)

\begin{tabular}{llrrrrr}
\hline Model & & Sum of Squares & df & Mean Square & F & Sig. \\
\hline 1 & Regression & .304 & 3 & .101 & 7.600 & $.003^{\mathrm{b}}$ \\
& Residual & .547 & 14 & .039 & & \\
& Total & .851 & 17 & & & \\
\hline
\end{tabular}

a. Dependent Variable: CDN_MYR

b. Predictors: (Constant), KURS_MYR, EKS_MYR, INFLS_MYR

Sumber: Data diolah, 2018

Dari tabel Anova diperoleh nilai F hitung sebesar 7.600 dengan signifikansi sebesar 0,003 . Dengan nilai signifikan sebesar 0,003 yang artinya lebih kecil dari 0,05 maka dapat disimpulkan bahwa secara simultan ekspor $\left(\mathrm{X}_{1}\right)$, inflasi $\left(\mathrm{X}_{2}\right)$ dan kurs $\left(\mathrm{X}_{3}\right)$ berpengaruh signifikan terhadap cadangan devisa Malaysia.

\section{Uji parsial (Uji t)}

Pengujian statistik parsial atau uji-t digunakan untuk pengujian terhadap pengaruh satu per satu variabel independen didalam model. Uji t pada dasarnya menunjukkan apakah semua variabel independen yang dimasukkan dalam model mempunyai pengaruh secara satu per satu terhadap variabel dependen.

Tabel 11. Hasil uji parsial (Uji t)

\begin{tabular}{llrrrrr}
\hline \multirow{2}{*}{ Model } & \multicolumn{2}{c}{$\begin{array}{c}\text { Unstandardized } \\
\text { Coefficients }\end{array}$} & \multicolumn{2}{c}{$\begin{array}{c}\text { Standardized } \\
\text { Coefficients }\end{array}$} & \multirow{2}{*}{ Sig. } \\
\cline { 3 - 5 } & \multicolumn{1}{c}{ B } & Std. Error & \multicolumn{1}{c}{ Beta } & & \\
\hline 1 & (Constant) & 6.160 & .699 & & 8.810 & .000 \\
& EKS_MYR & .005 & .068 & .015 & .072 & .944 \\
& INFLS_MYR & .305 & .217 & .304 & 1.408 & .181 \\
& KURS_MYR & -2.519 & 1.095 & -.494 & -2.301 & .037 \\
\hline
\end{tabular}

a. Dependent Variable: CDN_MYR

Sumber: Data diolah, 2018

Dari Tabel 11, dapat dijelaskan bahwa Ekspor $\left(\mathrm{X}_{1}\right)$, untuk variabel ekspor (X1) diperoleh nilai thitung sebesar 0,072 dengan tingkat signifikan sebesar 0,944. Hasil dari uji regresi menunjukkan bahwa secara parsial ekspor $\left(X_{1}\right)$ tidak berpengaruh terhadap cadangan devisa Malaysia $(\mathrm{Y})$ karena tingkat signifikan lebih besar dari 0,05. Inflasi $\left(\mathrm{X}_{2}\right)$, untuk variabelinflasi $\left(\mathrm{X}_{2}\right)$ diperoleh nilait hitung sebesar 1,408 dengan tingkat signifikan sebesar 0,181 . Hasil ini menunjukkan bahwa secara parsial inflasi $\left(\mathrm{X}_{2}\right)$ berpengaruh terhadap cadangan devisa Malaysia (Y) karena tingkat signifikan lebih besar dari 0,05. Kurs $\left(\mathrm{X}_{3}\right)$, untuk variabel kurs $\left(\mathrm{X}_{3}\right)$ diperoleh nilai t hitung sebesar 2.301 dengan tingkat signifikan sebesar 0,037. Hasil dari uji ini menunjukkan bahwa secara parsial kurs $\left(\mathrm{X}_{3}\right)$ berpengaruh terhadap cadangan devisa $(\mathrm{Y})$ karena tingkat signifikan lebih kecil dari 0,05.

\section{Uji koefisien determinasi $\left(\mathbf{R}^{2}\right)$}

Untuk mengetahui besarnya persentase pengaruh variabel bebas (independen) terhadap variabel terikat (dependen) yang dapat dilihat dari tabel berikut ini: 
Tabel 12. Hasil uji determinasi

\begin{tabular}{|c|c|c|c|}
\hline $\mathbf{R}$ & R Square & Adjusted R Square & Durbin-Watson \\
\hline $.598^{\mathrm{a}}$ & .358 & .220 & 1.629 \\
\hline
\end{tabular}

Sumber: Data diolah, 2018

Nilai R Square $=0,220$ dapat diarikan besarnya nilai ekspor $\left(\mathrm{X}_{1}\right)$, inflasi $\left(\mathrm{X}_{2}\right)$ dan kurs $\left(\mathrm{X}_{3}\right)$ mampu mempengaruhi cadangan devisa Malaysia $(\mathrm{Y})$ sebesar $22 \%$ sedangkan sisanya sebesar $88 \%$ dipengaruhi atau dijelaskan oleh variabel lain yang tidak termasuk dalam penelitian ini.

Nilai F hitung sebesar 6.868 dengan signifikansi sebesar 0,004. Dengan nilai signifikan sebesar 0,004 yang artinya lebih kecil dari 0,05 maka dapat disimpulkan bahwa secara simultan ekspor $\left(\mathrm{X}_{1}\right)$, inflasi $\left(\mathrm{X}_{2}\right)$ dan kurs $\left(\mathrm{X}_{3}\right)$ berpengaruh signifikan terhadap cadangan devisa. Nilai ekspor $\left(\mathrm{X}_{1}\right)$, inflasi $\left(\mathrm{X}_{2}\right)$ dan kurs $\left(\mathrm{X}_{3}\right)$ mampu mempengaruhi cadangan devisa Indonesia (Y) sebesar 50,9\% sedangkan sisanya sebesar 49,1\% dipengaruhi atau dijelaskan oleh variabel lain yang tidak termasuk dalam penelitian ini.

Nilai F hitung sebesar 7.600 dengan signifikansi sebesar 0,003. Dengan nilai signifikan sebesar 0,003 yang artinya lebih kecil dari 0,05 maka dapat disimpulkan bahwa secara simultan ekspor $\left(\mathrm{X}_{1}\right)$, inflasi $\left(\mathrm{X}_{2}\right)$ dan kurs $\left(\mathrm{X}_{3}\right)$ berpengaruh signifikan terhadap cadangan devisa Malaysia. Nilai ekspor $\left(X_{1}\right)$, inflasi $\left(X_{2}\right)$ dan kurs $\left(X_{3}\right)$ mampu mempengaruhi cadangan devisa Malaysia (Y) sebesar 22\% sedangkan sisanya sebesar $88 \%$ dipengaruhi atau dijelaskan oleh variabel lain yang tidak termasuk dalam penelitian ini.

Hasil dari uji regresi menunjukkan bahwa secara parsial ekspor $\left(\mathrm{X}_{1}\right)$ tidak berpengaruh terhadap cadangan devisa (Y) karena tingkat signifikan lebih besar dari 0,05. Hasil dari uji regresi menunjukkan bahwa secara parsial ekspor $\left(\mathrm{X}_{1}\right)$ tidak berpengaruh terhadap cadangan devisa Malaysia (Y) karena tingkat signifikan lebih besar dari 0,05.

Hasil ini menunjukkan bahwa secara parsial inflasi $\left(\mathrm{X}_{2}\right)$ berpengaruh terhadap cadangan devisa (Y) karena tingkat signifikan lebih kecil dari 0,05. Hasil ini menunjukkan bahwa secara parsial inflasi $\left(\mathrm{X}_{2}\right)$ berpengaruh terhadap cadangan devisa Malaysia (Y) karena tingkat signifikan lebih besar dari 0,05. Hasil dari uji ini menunjukkan bahwa secara parsial kurs $\left(\mathrm{X}_{3}\right)$ berpengaruh terhadap cadangan devisa $(\mathrm{Y})$ karena tingkat signifikan sama dengan 0,05 . Hasil dari uji ini menunjukkan bahwa secara parsial kurs $\left(\mathrm{X}_{3}\right)$ berpengaruh terhadap cadangan devisa (Y) karena tingkat signifikan lebih kecil dari 0,05.

Ekspor tidak berpengaruh terhadap cadangan devisa Indonesiakarena tingkat signifikan lebih besar dari 0,05. Ekspor tidak berpengaruh terhadap cadangan devisa Malaysiakarena tingkat signifikan lebih besar dari 0,05. Oleh sebab itu kedua Negara tersebut tidak perlu khawatir tentang berfluktuasinya nilai ekspor, karena hal tersebut tidak akan mempengaruhi cadangan devisa Negara. Inflasi berpengaruh terhadap cadangan devisa Indonesia karena tingkat signifikan lebih kecil dari 0,05. Inflasi berpengaruh terhadap cadangan devisa Malaysiakarena tingkat signifikan lebih besar dari 0,05 . Oleh sebab itu, kedua Negara tersebut harus terus berhati-hati dan terus menjaga kestabilan nilai inflasi. Kurs berpengaruh terhadap cadangan devisa Indonesia karena tingkat signifikan sama dengan 0,05. Kurs berpengaruh terhadap cadangan devisa Malaysia karena tingkat signifikan lebih kecil dari 0,05, oleh sebab itu kedua Negara tersebut harus tetap menjaga kestabilan nilai tukar mata uang. 


\section{KESIMPULAN DAN SARAN}

\section{Kesimpulan}

Ekspor Indonesia ke Negara Malaysia periode 2000-2017 mengalami fluktuasi, inflasi Indonesia periode 2000-2017 mengalami fluktuasi, nilai tukar rupiah periode 20002017 mengalami fluktuasi dan cadangan devisa periode 2000-2017 mengalami fluktuasi. Inflasi $\left(\mathrm{X}_{2}\right)$ dan kurs $\left(\mathrm{X}_{3}\right)$ berpengaruh signifikan terhadap cadangan devisa Indonesia, sementara itu ekspor $\left(\mathrm{X}_{1}\right)$ tidak berpengaruh terhadap cadangan devisa Indonesia.

\section{Saran}

Indonesia harus berhati-hati terhadap kenaikan inflasi karena hal itu dapat mempengaruhi cadangan devisa secara negatif. Karena ekspor berpengaruh terhadap cadangan devisa maka, pemerintah harus terus memperhatikan terus perkembangan variable ini agar cadangan devisa terus terjaga.

\section{DAFTAR PUSTAKA}

Agnes. (2016). Pengaruh kurs, JUB, tingkat inflasi terhadap cadangan devisa. Jurnal Ekonomi Pembangunan. 5(10), 1077-1102

Agustina. (2014). Pengaruh ekspor, impor, nilai tukar rupiah dan tingkat inflasi terhadap cadangan devisa. Jurnal Wira Ekonomi Mikroskil, 4(02), 61-70

Amilia. (2007). Ekonomi Internasional. Graha Ilmu: Yogyakarta.

Desnky, Reyandi. (2018). Ekspor kopi Indonesia dan faktor-faktor yang mempengaruhinya. e-Jurnal Perdagangan, Industri dan Moneter. 6(1), 23-34

M Mustika, H Haryadi, \& S Hodijah. (2015).Pengaruh Ekspor dan Impor Minyak Bumi terhadap Pertumbuhan Ekonomi Indonesia, Jurnal Perspektif Pembiayaan dan Pembangunan Daerah, 2 (3), 107-118

Nopirin. (2000). Ekonomi moneter, Buku II, Edisi I. BPFE: Yogyakarta.

Noviantoro,B; E Emilia; \& YV Amzar. (2017).Pengaruh harga CPO, harga minyak mentah dunia, harga karet dunia dan kurs terhadap defisit neraca transaksi berjalan Indonesia, Jurnal Paradigma Ekonomika, 12 (1), 31-40

Priadi. (2000). Ekspor mendorong pertumbuhan atau pertumbuhan mendorong ekspor. Jurnal Ekonomi Pembangunan. 4(2), 147-161

Putra, Muslimin Andika. (2018). Pengaruh kurs dan harga ekspor terhadap daya saing ekspor komoditas unggulan Provinsi Jambi. e-Jurnal Perdagangan, Industri dan Moneter . 6(1), 45-61

Sugiyono. (2017). Metode penelitian kuantitatif, kualitatif dan R\&D. Alfabeta: Bandung.

Sukirno. (2004). Pengantar teori makroekonomi. Raja Grafindo Persada: Jakarta.

Yudiarti, Tri .(2018). Pengaruh utang luar negeri, tingkat suku bunga dan neraca transaksi berjalan terhadap nilai tukar rupiah terhadap dollar Amerika Serikat. e-Jurnal Perdagangan, Industri dan Moneter. 6(1),14-22 